\title{
The Brief Analysis of Online Information Literacy Instruction of Applied-type Undergraduate College Libraries
}

\author{
Xiao-zhong Li, Jian-guo Zhang, Li-li Zhang \\ Library, Shandong Uuniversity of Science and Technology Tai'an, Shandong Province, China
}

\begin{abstract}
A research about 60 applied-type undergraduate college net-libraries which are drawn from 670 applied-type undergraduate colleges shows, the Online Information Literacy Instruction (OILI) of applied-type undergraduate college libraries in our country has four drawbacks, such as it did not underline the features of cultivating the talents with applied competence and the content and form of OILI is single. So strengthen basic theory research, broadening the content of OILI, highlighting the individuality, enhances interaction and co-ordinate planning and sharing and some other ways are the future countermeasures to the sustained and healthy development of applied-type undergraduate library OILI.
\end{abstract}

Index Terms - applied-type undergraduate; college; library; online information literacy instruction.

\section{Introduction}

Application-oriented universities aim mainly to cultivate applied talents not only with certain knowledge, ability and comprehensive quality for production, construction, management, service and other front-line talents, but also to cultivate advanced applied talents of potential of sustainable development. Mr. Pan Maoyuan, a well-known educator, founder of Chinese higher education, divided our higher education into three such categories as research, application and occupational type with reference to international education classification standard [1]. According to this classification, most of all the 670 general undergraduate colleges belong to the applied undergraduate colleges, in addition to the 38 of the "985 Project" universities, 112 of the "211 Project" universities and other comprehensive research university and 1239 vocational (specialist)[2].The applied undergraduate colleges, of which the orientation of the development of philosophy, the way of running schools, the training objectives, the training specifications share almost the same characters are the main force of an important part of China's higher education and the popularization of its higher education. Because of this, the study of applied undergraduate colleges of this group has become one of the hotspot and focus of higher education research in our country in recent years, and The National Higher Education Research Committee of Application-oriented Universities also emerged in Chengdu in 2007 August as the times require[3].

The Online Information Literacy education (hereinafter referred to as the OILI)first began in the United States in the 1990s[4] of last century is a new mode of information quality education through interactive network teaching mode, based on the computer technology, network technology, digital communication technology and database technology and other modern technology means so as to foster and improve the user's Information knowledge, Information consciousness, Information ability and Information morality. The education activity is not restricted by space and time, emphasizing the teaching of individuation, with the features of strong autonomy, practical, and easy to interactive [5], and it has been more and more popular among college and university students. We carried out large-scaled random sampling surveys and analysis over the Internet on the basic situation and characteristics of OILI about the applied undergraduate colleges libraries in China In order to have a full and accurate understanding of the basic situation of the applied undergraduate colleges library about the implement of OILI, to be better at OILI according to the characteristics of cultivating the applied undergraduate talents, so that we sum up experience and lessons, and put forward development strategies to push the OILI work of the applied undergraduate colleges library of our country further along the right track of healthy and fast development and innovation.

\section{The Investigation about the Situation of Applied Undergraduate Colleges OILI}

The survey online was carried out in the form of random sampling, and the individuals whose web site can't open were connected by phone and by E-mail sending the questionnaire form to them, and it was in the form of combination of qualitative and quantitative, and the survey was fulfilled out between March 22, 2011 to May 10th.The investigation was among the websites of the 60 Libraries from the 670 Institutes of Applied Undergraduate Colleges above. Given that the development of university libraries largely depend on the region as well as the university's comprehensive strength, so for the sake of regional balance, the 60 library websites were randomly chosen respectively by the college numbers from the northeast, north China, east China, central China, south China, northwest and southwest areas, trying to make the data reflect the present situation of the applied undergraduate colleges OILI situation as well as possible in our country. The contents of the survey include: (1) the way of OILI applying, the name, the position in the library website, (2) the media format the OILI uses (such as ppt, FLASH, or audio, etc.), and openness degree; (3) the OPAC using guide, project training, freshman 
education on entering the libraries, database retrieval guide and virtual reference consulting, etc..

Investigation shows, out of the libraries of 60 applied undergraduate colleges, 53 of them have carried out OILI, accounting for $88.33 \%$. Among them, 50 libraries have carried out OILI by using library websites, accounting for $83.33 \%$; only 3 libraries have used both the library web sites and the online teaching system for OILI, accounting for 5\%; the names are various, such as: the OILI teaching and training, users education, readers training, one-hour lectures, lectures and training, information literacy education, database using guide, etc; And the OILI module is placed in the columns of consulting service, reader services, reference of the library web site by most libraries, located in the home page level of columns or the secondary columns of the libraries, with less linking.

The survey found, the main form of OILI media is the integration of doc., ppt., PDF and HTML format, however, the ratio of Flash, Video and Audio is obvious low; As for the contents of OILI, some take the open way, so that readers from outside colleges can browse and download the using guides of database and the training course wares, but most of the libraries have IP restrictions for some OILI contents, resulting in some OILI contents cannot be accessed and shared for external readers.

Investigation still shows, 38 of the 60 applied undergraduate colleges libraries provide the users with OPAC use tutorials, accounting for $63.33 \%$; 7 of them provide special training for different disciplines of professional readers, accounting for $11.67 \%$; 14 libraries provide special training for readers of different levels, accounting for $23.33 \%$; 22 libraries have conducted online freshman guide into the library, accounting for $36.67 \%$; 25 libraries are supplied with database retrieval operation guide, accounting for $41.67 \%$; 44 carried out FAQ, QQ online consultation, real-time quiz, Email consultation and other forms of virtual reference service, accounting for $73.33 \%$; only 2 of the 3 libraries which have the Literature Information Retrieval and Utilization Course of network teaching system of the library provide online practice test, only accounting for $3.33 \%$; Libraries having online information literacy evaluation system is blank.

\section{Analysis of the Existing Problems of Application- Oriented Universities Library OILI}

The survey results show that with the development of network technology, multimedia technology, and the development of computer technology, the web-based OILI has increasingly become the main form of information literacy education for applied undergraduate colleges' libraries, and it is an inevitable trend for the development of educating readers. Applied undergraduate colleges library of OILI seem to cover OPAC searching guide Tours, special training, freshmen instructions, guide to network database retrieval, reference consultation, and the online teaching of "literature information retrieval and utilization course" , but the content is mainly focused on the information retrieval ability, etc.. But compared the university libraries of the developed countries such as the United States, in Australia[6] with China's "985 project", "211 project" university libraries[7], the applied undergraduate colleges OILI libraries in our country still exist the following problems and the insufficiency.

\section{A. Applied Undergraduate College Libraries OILI without the Characteristics of the Application-Oriented Talents \\ Compared with"985 project", "211 project" university} libraries, the applied undergraduate colleges' library OILI fails to show their own characteristics both in form and content. It does not keep pace with The Times, without closely aiming at the target of cultivating the talents of applied undergraduates, or exploring and summarizing applied undergraduate talents cultivation pattern, or carrying on the target-oriented docking, change and innovation. It is still following an imitation of academic research universities OILI in orientation, content, methods, etc., causing the quality and effect of applied undergraduate colleges' library OILI seriously restricted, therefore, the students' ability to improve information literacy and innovation are seriously affected.

\section{B. The Content and the Way of Applied Undergraduate Colleges' Library OILI is Quite Single}

It is rich in the connotation of information quality education, it not only includes the traditional library education of readers, It also includes the technology of using computers, network technology education, information retrieval technology, information awareness education, information morality and law education, etc. But the survey have found that for most of the applied undergraduate colleges libraries, the OILI is basically a literature retrieval skills education, it just unilaterally releases some rules and regulations, resources, OPAC searching, and retrieval database using the simple information such as lecture courseware of quality education on its web site in the form of web page files, ppt, Word document or PDF files. It doesn't have the development of different teaching courseware according to different grades, different majors, different levels of students, teachers and library staffs, etc., it only sets up the same content of information quality education for all the students of the school. The coverage of teaching content is too limited. It's not systematic enough, and the structure is badly organized and it lacks of audio, video, teaching media, so it is difficult to guarantee the readers' learning performance.

\section{The Application Objects of Applied Undergraduate Colleges' Library OILI are not Wide Enough}

The Information Literacy and Meeting of Experts organized by The United Nations educational, scientific and cultural organization and The American Committee of library Information Science, 40 representatives from 23 countries on behalf of The seven continents, issued a "Declaration of Prague: Marching Towards an Information Society" on September 23, 2003. The declaration has realized that it is one of the important challenges facing today's society how to make the people benefit from the Internet in the era of information and communication resources and technology, announcing that 
the lifelong learning of information quality is a kind of basic human rights[8].But the universality and the popularity of this nationwide information quality education in our country is not optimistic, research shows that in our country the applied undergraduate colleges library OILI has narrow objects, It is only limited to college students, some are restricted to students but the off-campus readers are not included.

\section{Applied Undergraduate Colleges OILI Libraries Lack of Overall Planning, Management and Lack of Collaboration}

At present, most of the applied undergraduate colleges' libraries explore patterns of OILI according to their own conditions. They are independent, self development, lack of cooperation between each other, mostly redundant construction, not unified norms and standards for making teaching courseware and development standard, the generality of teaching resources developed is not strong enough, difficult to share with each other, it lacks of overall planning and management of authority, thus causing serious waste of manpower and resources. Applied undergraduate colleges library OILI, on the other hand, lacks of effective cooperation of each department and administrative department, and without the support of each department or relevant administrative departments and cooperation, it is hard to do OILI relying on the library itself, and it is more difficult to guarantee to bring OILI personalized education advantage into full play.

\section{The Development Countermeasures of Applied Undergraduate Colleges OILI Library}

\section{A. It is Imperative to Strengthen Fundamental Theory Research of Applied Undergraduate Colleges OILI}

It is blind practice without the guiding of theories. The successful experience of American colleges' information literacy education also tells us that only by strengthening theoretical study can we promote the development of information literacy education [9]. In order to do some research about the "985 project", "211 project" university libraries and then work out the gain and loss of OILI in our country, we should not only draw lessons from the successful implementation of OILI case in university libraries of the developed countries such as Europe and America, But also do some key research about our present situation, the characteristics of applied undergraduate education, and combine closely with the applied undergraduate talents training targets, training specifications, training plans and training systems, trying to get a feasible pattern of applied undergraduate colleges OILI library implementation respectively from the macro level and micro level abstraction. We should try to improve it on the basis of pilot, demonstration and summarizing in a well-planned way and well-organized way, in order to promote innovation and development of applied undergraduate colleges OILI library effectively.

\section{B. Broaden the Content, and Enrich the Approaches of OILI.}

British Intute virtual training system provides more than 65 professional knowledge navigation and information literacy education, and all the 65 OILI platform of sub module covers almost all of the professionals of British university [10]. Applied undergraduate colleges OILI content library must have a clear teaching object, strong pertinence. Education content should be hierarchical, specialized, with its discipline characteristics and vary according to the identity of the readers (such as a freshman, senior students, teachers, library staff and readers outside schools, etc.), and should cooperate with various departments of professional teachers, organizing the teaching content of different levels. A joint working group of Australia and New Zealand college information literacy officially released in 2004"the Australian and New Zealand information literacy framework, principles, standards and practices", One of the standards for establishing information literacy is " to obtain and use information reasonably and legally" [11], because information law and moral education are very important parts for universities OILI in countries such as Australia and New Zealand. The content of applied undergraduate colleges' library OILI in our country ought to include information consciousness education [12], information ability education and information ethics education, information consciousness and information moral education should be set to different levels of general content of the teaching goals.

In order to arouse the reader's interest in learning and motivation, applied undergraduate colleges library virtual should also stress the interaction of online teaching, meanwhile the two teaching forms of online and traditional teaching should be combined well. Online teaching has features of crossing space and time, huge amounts of information and free accesses, with rich and colorful manifestations such as: BBS or electronic teaching materials, teaching video, QQ group, etc.; Use multimedia technology, combine printed contents with written contents, enhancing the feelings of visual and stereo; Use asp technology to realize knowledge network links, convenient for knowledge retrieval and concept section cross; Combine them with actual lecture or teaching, supplementing each other, and enlarge the influence of teaching, enhance readers' learning efficiency and effectiveness.

\section{Highlight Individuation, Enhance Interactivity}

With the fast development of network technology and the abundant network resources, readers increasingly need personalized services [13]. Applied undergraduate colleges OILI library need to be able to satisfy the demands of different content and different levels of learning, learning environments based on certain problems, the course map and hyperlinks must be provided, achieving a deeper level of content customization services. Adjust dynamically and provide the readers with different teaching contents based on the existing knowledge or a particular problem which interest the readers, facilitating readers to go through from chapter to chapter or just choose whatever they need. Provide different levels of teaching contents to readers based on the readers' information 
literacy by using methods such as testing in advance to understand actively readers' levels of learning. We must also provide a variety of approaches to learning, including Flash, voice, text, images, etc., so that it is easy for readers to adapt to the readers' network bandwidth and transmission speed difference.

Interactivity is one of the important characteristics of OILI when using computer technology and Web technology, it directly affects the reader education effect and the reader's interest in learning. Network interaction technology includes synchronous and asynchronous communication tools. Synchronous communication tools mainly refer to opening a chat room, chatting in real time [14]; Asynchronous communication tools are such tools as Email, blogs, and wikis etc., while theme forum have both synchronous discussion functions and asynchronous publishing functions. The OILI of applied undergraduate colleges library should be good at using network interaction technology to provide reader with interactive operating practice, online help, online navigation [15], online tests, and other functions, including synchronous and asynchronous communication tools, fully realizing the reader's interaction with the system, taking the initiative to create a collaborative learning environment of constructivism learning theory.

\section{Overall Planning, Cooperative Development, Collaboration Coordination, Co-Construction and Sharing}

The implementation of the foreign information literacy education benefits from the overall planning and management of authorities and of the association. In order to avoid low level and repeated construction, to save manpower and material resources, to improve the quality of the utilization of information resources and online repository, the ministry of education of higher school library intelligence, steering committee, CALIS center, national higher school teaching research association technical committee, the applied undergraduate colleges professional society or the organization collaboration alliance and so on should take the lead to work out the norms and standards, unify planning OILI resources, jointly participate in the course content development and maintenance, coordinate the courseware contents, courseware production characteristics, taking their own responsibilities to organize communities of distributed, cooperatives and integrate all kinds of characteristic resources of virtual learning, realizing the co-construction and sharing of information resources through the network.

\section{Conclusions}

Applied undergraduate education is a new type of higher education which is becoming increasingly distinct with our country's higher education changing from the elite education to popular education stage at the end of the 20th century, and applied undergraduate colleges have become the main body of popularization of higher education in our country. But so far few scholars have dabbled in the study of OILI in the applied undergraduate college. Only by tracking the latest research results of OILI and the research trend at home and abroad, by closely combining with the actual situation of the applied undergraduate colleges, drawing lessons, having the courage to explore, paying equal attention to theory and practice, inheritance and innovation, can we effectively promote the OILI implementation of applied undergraduate colleges in our country.

\section{References}

[1] Maoyuan Pan. My opinion of Applied Undergraduate College Orientation. Exploring Education Development, 2007(z1), pp. 34-36(in Chinese).

[2] Ministry of Education of the People's Republic of China. The list of Colleges and Universities with General Higher Education Entrance Qualification in 2010. China Education Daily, 2010.04.28, pp. 11-12.

[3] Wen Zhong. The Holding of Applied Undergraduate College Special Committee Founding Conference. Chengdu Daily, 2007.08.07:5.

[4] Linlin Song. Survey and Analysis of Online Information Literacy Instruction in Top 20 Academic Libraries in American. Library and Information, 2007(5), pp. 68-72.

[5] Christine Furino. Information literacy : getting the most from your 60minutes. Reference Service Review, 2008, 36(3), pp. 264-265.

[6] Jintao Gong, Yuwen Jia. Survey and Analysis about Online Information Literacy Instruction of the Top 16 Australian University Libraries. Research on Library Science, 2009, (3), pp. 78-81,85.

[7] Hui Wang. Survey and Analysis of Online Information Literacy Instruction in"211 Project" Universities of China. Library and Information, 2007(5), pp. 79-82.

[8] Thompson, S. Information Literacy Meeting of Experts. Prague, the Czech Republic. http://ib.colostate.edu/instruction/workshops/goodforbusiness.html

[9] YI Bin. The successful experience and revelations on the information quality education of American college and universities. Library, 2006(6), pp. 64-66.

[10] Linlin Song, Haitao Li. Construction and Inspiration National online education platform VTS Information Quality. Document; Information \& Knowledge, 2008, (3), pp. 92-97.

[11] Australian and New Zealand information literacy framework: principles, standard and practice. http://www.anziil.org/resources/Info lit 2nd edition pdf

[12] Christine Furino. Information literacy : getting the most from your 60minutes.Reference Service Review,2008,36(3):264-265.

[13] Jintao Gong, Yuwen Jia. Survey and Analysis about Online Information Literacy Instruction of the Top 16 Australian University Libraries. Research on Library Science, 2009, (3):78-81, 85 (Ch).

[14] Siti Salwah SALIM. Eliciting Specification for a Web-Based DistanceLearning System from Lecturers and Students in Malaysia. Asian Journal of Distance Education , 2006 , 4 ( 1 ) :56-66.

[15] Australian and New Zealand information literacy framework: principles, standard and practice. [2011-04-03]. http://www.anziil.org/resources/Info lit 2nd edition PDF. 